\title{
Quality of wheat flour and oat flour mixes for flour tortilla
}

\section{Calidad de mezclas de harina de trigo y harina de avena para tortilla de harina}

\author{
MORALES-GUZMAN, Víctor†*, MARTÍNEZ-CRUZ, Eliel and MARTÍNEZ-CRUZ, Rosa Arely \\ Universidad Tecnológica de Xicotepec de Juárez, Área Agroindustrial Alimentaria.
}

ID $1^{\text {st }}$ Author: Víctor, Morales-Guzman / ORC ID: 0000-0003-3098-2124, Researcher ID Thomson: S-7585-2018, CVU CONACYT ID: 320063

ID $1^{\text {st }}$ Coauthor: Eliel, Martínez-Cruz / CVU CONACYT ID: 211136

ID $2^{\text {nd }}$ Coauthor: Rosa Arely, Martínez-Cruz / CVU CONACYT ID: 1012668

DOI: $10.35429 / J U R R E .2019 .4 .3 .7 .10$

Received March 01, 2019; Accepted June 30, 2019

\begin{abstract}
Wheat grain is the cereal of great importance in the world for its baking characteristics. Oatmeal is a cereal rich in protein value, omega-6 unsaturated fats, insoluble and soluble fiber. The objective of this research was to characterize formulations of wheat flour with oat flour depending on their aptitude for tortillas. The Wheat used is of the UrbinaS2007 variety, treatments of a control were formulated with $100 \%$ of Wheat Flour (TE) and three formulations with 5\% of Oat Flour(T1), $10 \%$ of Oat Flour(T2) and $15 \%$ of Oat Flour(T3). A simple Anova was applied with a comparison of tukey mean at $\mathrm{P}=0.95$. Significant difference was determined in the Sedimentation of $\mathrm{TE}(\mathrm{Sed})=42.5 \mathrm{~mL}$ at $\mathrm{T} 3(\mathrm{TDS})=35.9 \mathrm{~mL}$; alvegraphic parameters Tenacity of $\mathrm{TE}(\mathrm{P})=42 \mathrm{~mm}$ to $\mathrm{T} 3(\mathrm{P})=66$ $\mathrm{mmH} 20$, Extensibility of $\mathrm{TE}(\mathrm{L})=63 \mathrm{~mm}$ to $\mathrm{T} 3(\mathrm{~L})=16$ $\mathrm{mm}$, Force of mass TE $(\mathrm{W})=7010 \mathrm{E}-4 \mathrm{~J}$ to $\mathrm{T} 3(\mathrm{~W})=48$ 10E-4J; Mixigrafic of Mixing Time TE(MT)=2.9 min at $\mathrm{T} 3(\mathrm{TA})=2.1 \mathrm{~min}$; Tortilla, Moisture Absorption $\mathrm{TE}(\mathrm{HA})=44.5 \%$ at $\mathrm{T} 3(\mathrm{HA})=46.5 \%$, Protein (TE)Prot $=10.4 \%$ a (T3)Prot $=10.9 \%$. The T3 treatment has desirable characteristics for a wheat flour tortilla.
\end{abstract}

Soft Wheat, Oat Flour \& Extensibility

\begin{abstract}
Resumen
El grano de trigo es el cereal de gran importancia en el mundo por sus características de panificación. La avena es una cereal rico en valor proteínico, grasas insaturadas omega-6, fibra insoluble y soluble. El objetivo de esta investigación fue caracterizar formulaciones de harina de trigo con harina de avena en función de su aptitud para tortilla. El Trigo utilizado es de la variedad UrbinaS2007, se formularon tratamientos testigo con $100 \%$ de Harina de Trigo(TE) y tres formulaciones con 5\% de Harina de Avena(T1), 10\% Harina de Avena(T2) y $15 \%$ de Harina de Avena(T3). Se aplicó un Anova simple con una comparación de media de tukey a $\mathrm{P}=0.95$. Se determinó diferencia significativa en Sedimentación de $\mathrm{TE}(\mathrm{Sed})=42.5 \mathrm{~mL}$ a T3=35.9 mL; alvegráma Tenacidad de $\mathrm{TE}(\mathrm{P})=42 \mathrm{~mm}$ a $\mathrm{T} 3(\mathrm{P})=66$ $\mathrm{mm}$, Extensibilidad de $\mathrm{TE}(\mathrm{L})=63 \mathrm{~mm}$ a $\mathrm{T} 3(\mathrm{~L})=16 \mathrm{~mm}$, Fuerza de la masa $\mathrm{TE}(\mathrm{W})=70 \mathrm{E}-4 \mathrm{~J}$ a $\mathrm{T} 3(\mathrm{~W})=48 \mathrm{E}-4 \mathrm{~J}$; mixográma-Tiempo de Amasado $\mathrm{TE}(\mathrm{TA})=2.9 \mathrm{~min}$ a $\mathrm{T} 3(\mathrm{TA})=2.1 \mathrm{~min}$; tortilla, Absorción de Humedad $\mathrm{TE}(\mathrm{HA})=44.5 \% \quad$ a $\mathrm{T} 3(\mathrm{HA})=46.5 \%, \quad$ Proteína (TE)Prot $=10.4 \%$ a (T3)Prot $=10.9 \%$. El tratamiento(T3) posee características deseables para tortilla de harina de Trigo.
\end{abstract}

Trigo Suave, Avena \& Extensibilidad

Citation: MORALES-GUZMAN, Víctor, MARTÍNEZ-CRUZ, Eliel and MARTÍNEZ-CRUZ, Rosa Arely. Quality of wheat flour and oat flour mixes for flour tortilla. Journal-Urban-Rural and Regional Economy. 2019. 3-4: 7-10

\footnotetext{
* Correspondence to Author (email: victor.morales@utxicotepec.edu.mx)

$\dagger$ Researcher contributing as first author.
} 


\section{Introduction}

In the Mexican population, wheat represents the second source of carbohydrates due to its consumption in bakery products of $44.2 \mathrm{~kg}$ per capita (CANIMOLT, 2006). The consumption of whole grain foods and their derivatives contributes significantly to healthy nutrition.

Wheat flour tortilla sales in 2015 amounted to 118 thousand tons per year. In the case of wheat flour tortillas, their consumption has historically predominated in the northeast and north of the country and from the participation of the bakery industry through mechanisms of production, distribution and consumer spending has been distributed to practically all the country, so currently its participation in wheat products amounts to $7 \%$ of national consumption and 5\% of household expenditure. $51 \%$ of consumers buy flour tortillas in grocery stores and $23 \%$ in self-service stores (CANIMOL, 2016).

Therefore, the objective of this work was to evaluate the quality of the formulations of wheat and oatmeal based on sedimentation tests, rheological mass tests with the mixograph and alveographic and quality tests of baking-tortilla flour.

\section{Developing}

In 2018, the annual wheat production in Mexico was 3,139,142 tons with an average yield of 6.03 tons / ha. The annual production of Avena was 13,147 tons with a yield of 3.24 tons / ha (SIAPSAGARPA, 2018).

According to Salazar et al. (2000), protein content and quality determines the industrial use of wheat flour; Soft wheat flours with a high protein content (9-11\%) are preferably used as raw material for the production of biscuits. The functional quality of wheat protein is determined by the composition of glutenins and gliadins that form gluten. The gliadin fraction contributes to extensibility and cohesiveness (Hoseney, 1991).

Obesity and overweight are current conditions that affect $52 \%$ of Mexicans; The costs for care and treatment of associated diseases exceeds 82 billion pesos annually, so the Federal Government has undertaken a series of actions aimed at the prevention and control of such diseases.
Limit the sale of food in schools, installation of school drinking fountains, restrictions on advertising, lien for foods with high caloric content (IEPS), modification of the frontal labeling and nutritional label, campaigns to promote and disseminate physical activities and periodic medical visits, among others (CANIMOL, 2016).

Oatmeal is the only cereal that has significant amounts of lipids in the endosperm, these are characterized by being of high nutritional quality. Oatmeal is characterized by its high fiber content. Oatmeal is the cereal with the highest protein content, although these have functional properties for baking (Hosseney, 1991).

Based on the above, there is a need to promote products that favor the health of the Mexican consumer, so that products based on whole grain oatmeal and wheat flour can be a source of protein of excellent nutritional quality and fiber.

\section{Methodology Developed}

The evaluation of the quality of mixtures of refined wheat flour-oatmeal was carried out in the Experimental Field of the Valley of Mexico (CEVAMEX-INIFAP) in the Wheat Quality Laboratory, located at Km 13.5 Los Reyes Texcoco road, Coatlinchán, Texcoco, State of Mexico. The wheat variety Urbina S2007 was grown under irrigation conditions in the experimental field of Bajío in Roque, Guanajuato during the Autumn-Winter 20172018 agricultural cycle. The Turquoise Oat variety was grown under temporary conditions during the spring-summer 2017-2018 cycle; both produced in the Experimental Field of the Valley of Mexico, in Santa Lucia, Coatlinchán, Texcoco, Mexico.

Wheat grain samples were determined the hectolitre weight by the method (AACCMethod 55-10), hardness by the bolting method (AACC Method 55-20), moisture and protein by the FOSS NIR System method (AACC Method 39 -10). Once the wheat was conditioned, it was ground with the Brabender Mill Model 880-200 (AACC Method 26-20). Oat grains underwent threshing, cleaning. Subsequently the oatmeal was dried at $75^{\circ} \mathrm{C}$ for $48 \mathrm{hrs}$. The milling to obtain flour was done with the Buhuler Wheat Mill. The standard sieve mesh was $0.8 \mathrm{~mm}$. 
From the previously sifted flours, the mixtures were dosed and homogenized on the basis of formulation to assess the ability of flour tortillas. The mixtures that were dosed are the following combinations: $100 \%$ Refined Wheat Flour (TE), 5\% Oatmeal (T1), 10\% Oatmeal (T2) and 15\% Oatmeal (T3).

The repetition of the treatment weighs $500 \mathrm{~g}$. The flour mixtures were determined moisture and protein by the near infrared spectrophotometry method, using the automated FOSS NIR System (AACC Method 39-10), sedimentation using the Zeleni method (AACC Method 56-61). The rheological evaluation of the masses was determined by using the $60 \mathrm{~g}$ Chopin alveograph using the Alveolink NG software (AACC Method 54-30) and the $10 \mathrm{~g}$ mixograph (AACC Method 54-40). Next, the tortillas were prepared evaluating Absorbed Humidity (\%), Pre-cooked Tortilla Weight in (g), Tortilla Weight After Cooking (g), PreCooked Tortilla Diameter $(\mathrm{cm})$ and After Cooking Diameter $(\mathrm{cm})$. A sensory analysis was performed with an untrained panel of 30 people. Tortillas made with formulations were evaluated with a preference test based on taste, texture and color. The experimental design was a Simple ANOVA with the 4 treatments of the formulations of wheat flour refined with oatmeal and three repetitions. Comparison test of means was applied by the Tukey test at $\mathrm{P} \leq 0.05$ using SAS Sistem version 9.1 software for statistical analysis (SAS, 2002).

\section{Results}

\section{Quality characterization of flour mixtures}

Table 1 shows the means for the variables of humidity, sedimentation and myxogram.

\begin{tabular}{|l|l|l|l|l|}
\hline \multicolumn{1}{|c|}{ Mixture } & \multicolumn{1}{c|}{$\begin{array}{c}\text { HH } \\
(\mathbf{\%})\end{array}$} & \multicolumn{1}{c|}{$\begin{array}{c}\text { VS } \\
(\mathbf{m l})\end{array}$} & $\begin{array}{c}\text { PROT } \\
(\mathbf{\%})\end{array}$ & $\begin{array}{c}\text { TA } \\
(\mathbf{m i n})\end{array}$ \\
\hline TE (100\% HTR) & $10.9 \mathrm{a}$ & $42.5 \mathrm{a}$ & $10.4 \mathrm{~b}$ & $2.9 \mathrm{a}$ \\
\hline T1 5\% HA & $11.0 \mathrm{a}$ & $40 \mathrm{~b}$ & $10.4 \mathrm{~b}$ & $2.8 \mathrm{~b}$ \\
\hline T2 10\% HA & $10.9 \mathrm{a}$ & $36.6 \mathrm{c}$ & $10.6 \mathrm{ab}$ & $2.2 \mathrm{c}$ \\
\hline T3 15\% HA & $10.9 \mathrm{a}$ & $35.9 \mathrm{c}$ & $10.9 \mathrm{a}$ & $2.1 \mathrm{c}$ \\
\hline $\begin{array}{l}\text { HH = moisture in flour }(\%) ; \text { VS }=\text { sedimentation volume }(\mathrm{ml}) ; \text { PROT } \\
\text { = Protein; and TA = kneading time (min). Means with different letters } \\
\text { in the same column are significantly different }(\alpha=0.05) .\end{array}$ \\
\hline
\end{tabular}

Table 1 Comparison of Moisture, Sedimentation Volume, Protein and Kneading means of mixtures of refined wheat flour (TE) and oatmeal (HA)

The highest sedimentation volume (VS) for the TE (100\% HTR) was $42.5 \mathrm{~mL}$ coincides with Solís et.al. (2008), while the T3 (15\% HA) was the lowest value with $35.9 \mathrm{~mL}$.
Protein content is very similar, it varies from $10.4 \%$ in TE to $10.9 \%$ in T3. In the case of kneading time (TA), TE presented the highest TA with 2.9 min and the lowest TA3 presented $\mathrm{TA}=2.1 \mathrm{~min}$. Table 2 shows the means of the alveographic variables of the mass.

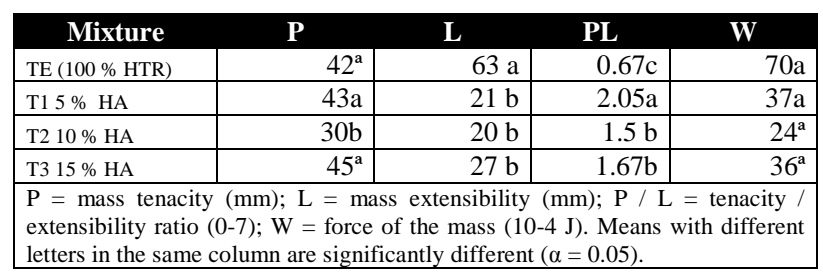

Table 2 Comparison of means of alveographic variables of refined wheat flour (HTR) and oatmeal (HA) mixtures

Tenacity values varied from $45-30 \mathrm{~mm}$, the highest value being for $\mathrm{T} 3$ with $\mathrm{P}=45 \mathrm{~mm}$. In the case of extensibility (L), the TE indicated the greatest extensibility $\mathrm{L}=63 \mathrm{~mm}$ and the $\mathrm{T} 3$ was less extensibility $\mathrm{L}=7.5 \mathrm{~mm}$. The tenacity / extensibility (PL) ratio varied from 0.67 to 1.67 . In the case of mass force (W) no statistical difference between mixtures was detected.

Based on the above, the addition of 5\%, $10 \%$ and $15 \% \mathrm{HA}$ in formulations with HRT does not affect the toughness $(\mathrm{P})$ and produces a decrease in the extensibility (L) of the mass, consequently the toughness / Extensibility (PL) increases. The above indicates that Oat protein is inelastic and not extensible. These results agree with Morales et. to the. (2015) who indicated that this behavior is due to the fact that oatmeal does not present the functional gliadin proteins associated in wheat flour due to the extensibility characteristics of the dough, which favor the bread-making characteristics for wheat tortillas (Peña et al .; 2015).

\section{Quality characterization of flour mixtures for Flour Tortilla}

Table 3 shows the parameters evaluated to determine flour tortilla quality.

\begin{tabular}{|c|c|c|c|c|c|c|c|}
\hline Mixture & HA & PPC & PC & PEC & DPC & DC & PEDC \\
\hline $\mathrm{TE}(100 \% \mathrm{HTR})$ & $44.5 b$ & $19.2 \mathrm{a}$ & $16.5 \mathrm{~b}$ & $13.9 \mathrm{a}$ & $14.5 \mathrm{a}$ & $13.7 \mathrm{a}$ & $1.16 \mathrm{~b}$ \\
\hline T1 5\% HA & $45.2 \mathrm{ab}$ & $18.8 \mathrm{a}$ & $16.7 \mathrm{~b}$ & $11.8 \mathrm{~b}$ & $14.0 \mathrm{a}$ & $13.1 \mathrm{c}$ & $2.04 \mathrm{ab}$ \\
\hline $\mathrm{T} 210 \% \mathrm{HA}$ & $45.8 \mathrm{a}$ & $19.1 \mathrm{a}$ & $16.7 \mathrm{~b}$ & $12.1 \mathrm{~b}$ & $14.5 \mathrm{a}$ & $13.6 \mathrm{~b}$ & $2.76^{2}$ \\
\hline T3 15\% HA & $46.5 \mathrm{a}$ & 19.1a & $17.1 \mathrm{a}$ & $10.3 \mathrm{c}$ & $14.3 \mathrm{a}$ & $13.5 \mathrm{~b}$ & $2.52^{2}$ \\
\hline \multicolumn{8}{|c|}{$\begin{array}{l}\text { HA = Absorbed Humidity }(\%) ; \text { PPC }=\text { Pre-cooked Tortilla Weight }(\mathrm{g}) ; \mathrm{PC}= \\
\text { Tortilla Cooking Weight }(\mathrm{g}) ; \mathrm{PEC}=\text { Weight Loss After Cooking }(\%) ; \mathrm{DDP}= \\
\text { Tortilla Pre-cooking Diameter }(\mathrm{cm}) ; \mathrm{DC}=\text { Diameter After Tortilla Cooking }(\mathrm{g}) \text {; } \\
\text { PED = Loss of Diameter After Cooking }(\%) \text {. Means with different letters in the } \\
\text { same column are significantly different }(\alpha=0.05) \text {. }\end{array}$} \\
\hline
\end{tabular}

Table 3 Comparison of means of quality variables of tortilla mixtures of refined wheat flour (HTR) and oatmeal (HA) 
According to the functionality evaluation of the flour tortilla samples, the dough indicated a moisture absorption between $46.5 \%$ (T3) to $44.5 \%$ (TE). There were no significant differences in the variables of Pre-cooked Tortilla Weight (PPC) and DPC Tortilla Diameter. Weight Loss After cooking ranged from $10.3 \%$ (T3) to $13.9 \%$ (TE). This indicates that the protein and carbohydrates provided by oatmeal favor the retention of water in the product. Loss of Diameter After Cooking was from $2.76 \%$ (T2) to $1.16 \%$ (TE), which is related to the toughness produced by the inclusion of oat protein in formulations.

The sensory evaluation of an untrained panel of 30 people indicated that flour tortillas made on the basis of treatments do not exist differences. The sensory attributes of taste, texture and color indicated evaluations of likes and likes by the panelists.

\section{Acknowledgments}

To the Researchers of the INIFAP-Experimental Field of the Valley of Mexico, Program of Genetic Improvement of Wheat and Oats for the facilities in this study. To the authorities of the UT of Xicotepec for facilitating teacher and student mobility to develop the Research project.

\section{Conclusions}

The incorporation of oatmeal (HA) of 5\%, $10 \%$ and $15 \%$ in formulations with refined wheat flour (HRT), decreased the volume of sedimentation (VS), did not change the toughness $(\mathrm{P})$, decreased the extensibility $(\mathrm{L})$ and increase the tenacity / extensibility ratio (PL).

On the other hand, in the range evaluated, the percentage of moisture absorption was higher as the proportion of oatmeal (HA) increased, the percentage of moisture loss of the tortilla after cooking decreased, although the percentage of loss of Tortilla diameter decreased, property related to superior protein content. The inclusion of oatmeal in flour tortilla formulations is functional in the range evaluated. The sensory attributes of the product are similar.

\section{References}

American Association of Cereal Chemists (2005). Approved Methods of the AACC, 10th ed. The Association: St. Paul, MN.

CANIMOLT (2006). Cámara Nacional de la Industria Molinera de Trigo. WWW.CANIMOLT.ORG. Julio, 2016.

CANIMOLT (2016). Cámara Nacional de la Industria Molinera de Trigo. WWW.CANIMOLT.ORG. Agosto, 2016.

Hosseney, R.C. 1991. Principios de Ciencia y Tecnología de los cereales. Editorial Acribia. Zaragoza, España. 321 p.

Morales Víctor, Martínez Eliel, Espitia Eduardo y Bardomiano Jaime (2015). Evaluación de calidad de mezclas de harina de avena y harina de trigo para galleta. Revista de Ciencias Naturales y Agropecuarias 2015, 2-4: 608-615.

Peña Bautista, R.J.; Villaseñr Mir, H.E.; Martínez Cruz E.; González Santoyo, H.; Autrique Ruiz, E.; Guzmán, C. (2015). Calidad Industrial de variedades Mexicanas de Trigo Harinero. México, D.F.: CIMMYT.

Salazar, Z. A. (2000). Calidad industrial del trigo para su comercialización. El Trigo de Temporal en México. HE Villaseñor, E Espitia (eds). SAGAR, INIFAP. México. pp, 192-207.

SAS Institute (2002). SAS/STAT User's Guide: GLM VARCOMP. 6.04. Fourth ed. Cary, NC, USA. pp: 996.

SIAP-SAGARPA (2018). Servicio de información y Estadística Agroalimentaria y Pesquera. Obtenido de la red. www.siap.gob.mx. Diciembre, 2018.

Solís Moya, E., Huerta Espino, J., Pérez Herrera, P., Ramírez Ramírez, A., Villaseñor Mir, H. E., Espitia Rangel, E., \& Borodanenko, A. (2008). Urbina S2007: nueva variedad de trigo harinero para la región 'El Bajío'. Agricultura técnica en México, 34(1), 113-118. 